Li, Y., Xue, F., Jing, R., Wang, Y., \& Wang, J. (2019). Study on Water-City Pattern Strategies of ShenShan Special Cooperation Zone, China with Sponge City Construction at the Watershed Scale. Landscape Architecture Frontiers, 7(4), 104-113. https://doi.org/10.15302/J-LAF-1-040005

\section{中国深汕特别合作区 流域尺度海绵城市水城格局策略研究 STUDY ON WATER-CITY PATTERN STRATEGIES OF SHENSHAN SPECIAL COOPERATION ZONE, CHINA WITH SPONGE CITY CONSTRUCTION AT THE WATERSHED SCALE}

\author{
李毅* \\ 深圳市水务规划设计院股份有限公司研究发展中心部长、工程师 \\ 薛菲 \\ 深圳市水务规划设计院股份有限公司研究发展中心执行主任、高级工程师 \\ 景瑞瑛 \\ 深圳市水务规划设计院股份有限公司研究发展中心研究专员、工程师 \\ 王燕 \\ 深圳市水务规划设计院股份有限公司总规划师、教授级高级工程师 \\ 王健 \\ 深圳市水务规划设计院股份有限公司副总经理、教授级高级工程师 \\ LI Yi
}

Manager of Research and Development Center, and Engineer of Shenzhen Water Planning and Design Institute Co., Ltd.

XUE Fei

Executive Director of Research and Development Center, and Senior Engineer of Shenzhen Water Planning and Design Institute Co., Ltd.

JING Ruiying

Researcher of Resear

WANG Yan

Chief Planner and Professorate Senior Engineer of Shenzhen Water Planning and Design Institute Co., Ltd.

WANG Jian

Deputy General Manager and Professorate Senior Engineer of Shenzhen Water Planning and Design

Institute Co., Ltd.

\section{大通讯作者}

地址: 广东省深圳市罗湖区宝安南路3097号洪涛大廈701室

那编: 518022

邮箱: liy@swpdi.com
摘要

本研究聚焦于中国深汕特别合作区的水城 格局，探讨了从区域尺度转向流域尺度的海绵城 市建设策略，并从合作区面临的挑战出发，尝试 将流域空间建设要素与海绵城市相关控制指标进 行关联对应，为合作区未来的开发建设提供刚性 准则, 以确保整个流域的健康与安全。在水城格 局的具体构建中, 本研究详细讨论了海绵系统布 局、城市水系规划、土地开发模式三个方面的策 略, 通过高标准践行生态保育原则提升全域生态 资源占比, 通过加密水网、蓄泄兼筹防御风险保 障安全, 通过岛式开发、河滩利用、湖库保留、 坑塘拓展实现资源调蓄以带动土地开发的均衡发 展。在合作区即将进入高速发展之际，本方案通 过研究合作区水城关系构建策略, 探讨了通过流 域尺度的海绵城市建设促进绿色可持续发展的创 新思路。

关键词

流域; 海绵城市建设; 深汕特别合作区; 水城格 局；防洪

\section{ABSTRACT}

This article focuses on the water-city pattern development in the ShenShan Special Cooperation Zone in China and discusses the watershed-based sponge city construction strategy. Specific to the challenges of the zone, this study attempts to establish the correspondence between watershed spatial construction and the control indicators of sponge city, providing rigid norms for future urban development to ensure the safety and health of the whole watershed. At a practical level, three strategies of water-city pattern construction are proposed in aspects of 1) sponge system layout, to increase the proportion of the ecological resource across the watershed by a high-level ecosystem conservation; 2) urban waterway planning, to protect the zone from floods by increasing the water network density as well as introducing infrastructures for flood storage and discharge; and 3) land development mode, to regulate resources to achieve balanced land development by dividing the zone into many "islands," taking full advantage of flood plains, reserving the lakes and reservoirs, and introduce more ponds. As the zone is going to start high-speed development, this article studies strategies of the water-city pattern construction and discusses the innovation methods of promoting sustainable developmen with sponge city construction at the watershed scale.

\section{KEYWORDS}

Watershed; Sponge City Construction; ShenShan Special Cooperation Zone; Water-City Pattern: Flood Control

编辑 汪默英 王颖 翻译 肖杰 田晓劼

EDITED BY WANG Moying WANG Ying TRANSLATEd BY XIAO Jie TIAN Xiaojie 


\section{1 项目背景}

深汕特别合作区（以下简称 “合作区” ) 紧邻中国广东省珠江三 角洲平原东侧, 是奥港澳大湾区向奥东城镇群拓展辐射的重要战略节 点, 也是粤东地区通往珠江三角洲地区的桥头堡。其辖区范围包括原 海丰县鹅埠、小漠、眽门、赤石四镇, 总面积约 $468 \mathrm{~km}^{2}$ 。2011年 2 月, 合作区在广东省深人推进新时代改革开放和区域协调发展的背景下成 立，并于2017年正式成为深圳第 “10+1” 区 (图1)。

合作区地势北部多山, 中部为台地、丘陵, 南部为滨海平原。依 山面海, 林田交错, 水网密布, 湖库众多, 具有良好的海绵基底。其 资源包括北部莲花山脉的 $353 \mathrm{~km}^{2}$ 山林、 $36 \mathrm{~km}^{2}$ 耕地、6座小 (一) 型水 库、22座小 (二) 型水库、 $54 \mathrm{~km}$ 的滨海岸线、 $13 \mathrm{~km}$ 的优质连续沙滩、 水质达到 II III类的河流水系以及众多坑塘湿地。赤石河自北向南贯穿 合作区全境, 是该区域的主要河流, 除明热河和南门河两条一级支流 外，还有十余条小支流，流域面积达 $382 \mathrm{~km}^{2}$ ，占合作区面积的 $81.6 \%$; 此外, 还有部分独立入海的沿海小河, 总汇水面积占合作区面积的 18.4\%（图2）。

虽然具有良好的海绵基底，但合作区当前仍面临着诸多挑战：

1 ) 生态形势严峻: 受丘陵地貌限制, 合作区内适宜开发建设的土 地资源十分有限, 且集中分布于中部的河谷台地及南部的沿海平原地 区，约占合作区总面积的 $30 \%$ 。西部是合作区先行启动的产业组团，开 发带来的人水争地现象已经显现, 支流河道被改道、裁弯、填埋, 天 然湿地面积急剧减少，流域的生态水文过程遭到破坏。随着合作区发 展的加速, 用地需求进一步加剧, 对自然资源的干扰不可避免, 流域 生态安全面临严峻考验;
2 ) 洪涝风险加剧: 合作区海岸线绵长，极易遭受台风侵袭。区域 水系发达且比降大汇流快, 洪涝潮灾害频发。现状防洪基础设施整体 薄弱, 河道、海堤防御标准偏低, 难以抵御汛期暴雨洪水的侵袭。随 着合作区建成区面积不断扩大, 不透水率、径流系数、洪峰洪量大幅 升高, 将加剧城市洪涝风险, 威胁居民生命财产安全;

3 ) 淡水资源不足: 受地形影响, 从明热河汇人赤石河处至出海口 之间会受到咸潮影响, 使得本地可利用淡水资源变得十分有限。合作 区全域位于广东省地下水水源涵养区，地质灾害频发，地下水不宜进 行开发利用。淡水供需矛盾突出, 可持续利用面临挑战。

\section{2 技术路线}

海绵城市建设的核心价值在于维护城市生态系统的健康与安全 ${ }^{[1] 2]}$ 。 现行的海绵城市建设目标涵盖了水安全、水环境、水生态、水资源、制 度建设等方面 ${ }^{[3-[5]}$, 且已有大量研究聚焦于径流总量控制、径流峰值控 制、径流污染控制等核心指标 ${ }^{[6-[10]}$ 。本方案从合作区水城关系空间格局 出发, 针对城市建设中的海绵系统布局、新旧城区水系规划、土地开 发模式所涉及的海绵要素进行分析研究, 以流域水系为脉络, 以山一 水一林一田一湖等自然基底为载体，提出从区域尺度转向流域尺度的 海绵城市建设策略 ${ }^{[11]}$ 。

笔者所在团队结合国家层面与当地规范导则, 将流域空间建设要 素与海绵城市相关控制指标分项关联, 为合作区未来的土地开发建设 提供刚性准则，以确保整个流域的健康与安全 (图3)。

首先, 从海绵系统布局来看, 需重点关注通过生态保育指标, 控 制蓝绿空间占比。即使土地资源极度紧缺，《深圳市基本生态控制线

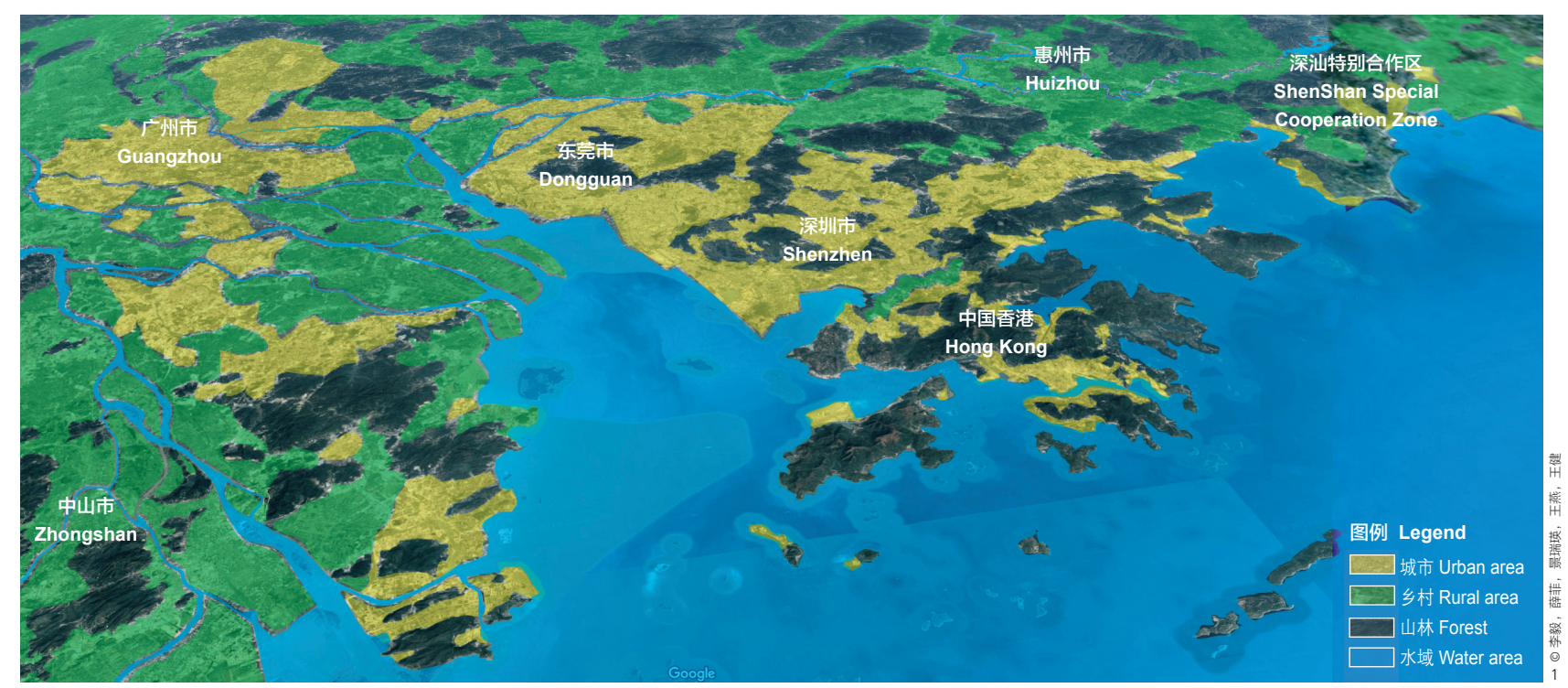




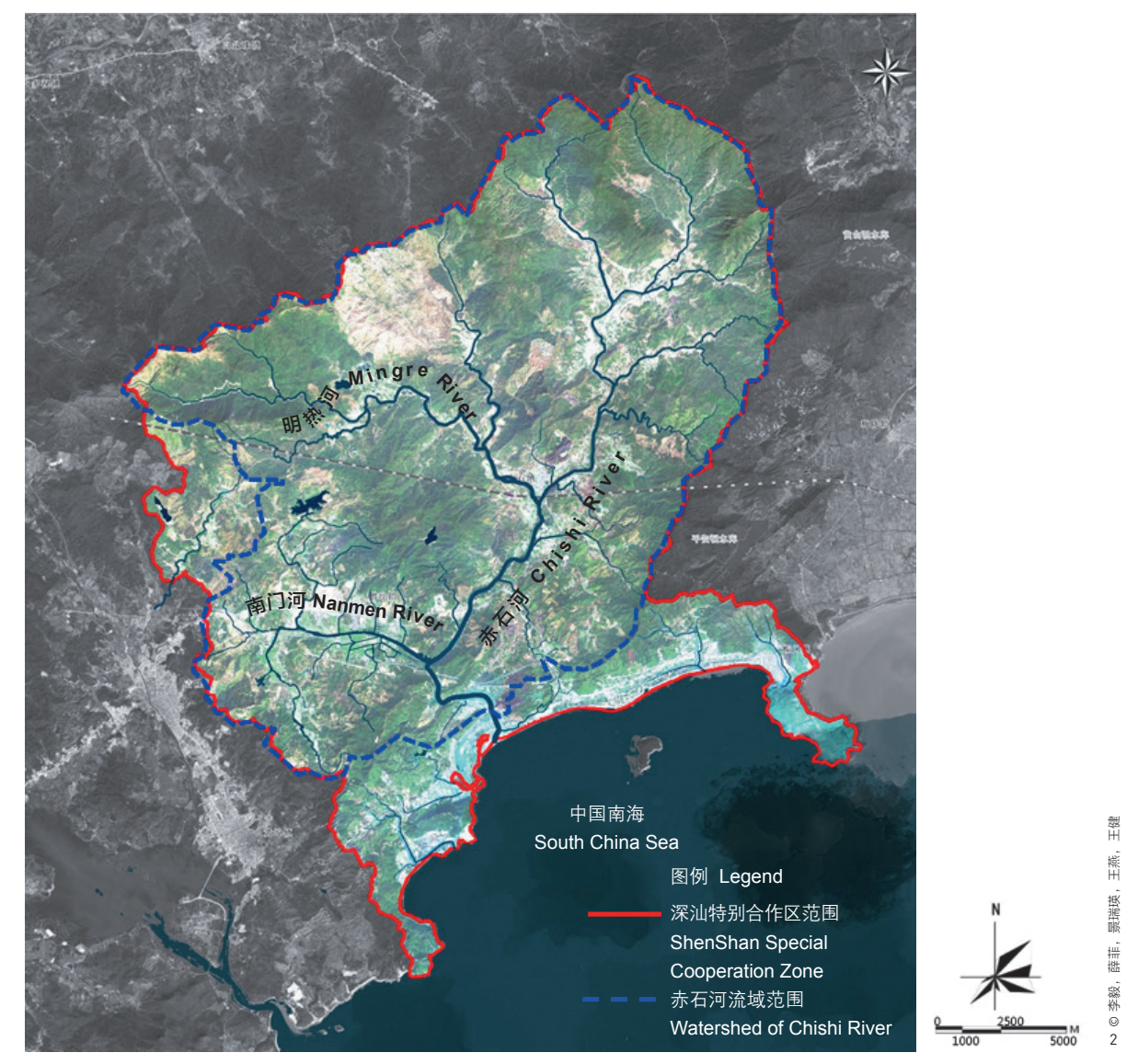

2. 流域主要水系分布

海绵城市水城格局构建 技术路线

2. Main rivers in the watershed

3. Roadmap for water-city pattern development with sponge city construction

管理规定（2005）》仍将近50\%的自然区域纳人了生态控制线保护范围 内 $^{[12]}$ 。由于现状全域蓝绿空间占比已达 $69.1 \%$, 研究方案对标雄安新区 “以水定城” 的创新理念和蓝绿空间占比 $70 \%$ 的目标要求 ${ }^{[13]}$, 略微提高 指标，拟将合作区蓝绿空间占比定为不低于全流域的 $70 \%$ ，以此来保障 城市生态服务功能的安全健康。

第二, 从城区水系规划来看, 方案划定了多维度高标准的安全 防御指标，且计划基于新旧城区不同的本底条件，采取不同的建设思 路。依据上位规划，合作区规划人口规模超过 150 万，因此隶属于I级 ( 特别重要) 防护等级, 需满足 200 年一遇的滨海防潮标准，主干河 网需满足200年一遇、其他河道需满足50 100年一遇防洪标准 ${ }^{[4]}$ 。而区 域内现状防潮标准仅为 100 年一遇，主干河网和其他河道的防洪标准 分别为 50 年一遇和 20 年一遇, 与目标存在较大差距。依据《治涝标准 （SL723-2016）》，城市涝区的设计标准将结合其经济地位、常住人 口数量或当量经济规模指标进行综合考虑 ${ }^{[14]}$ 。按照广东省《关于做好 城市排水防涝设施建设工作的意见（粤府办〔2014]15号）》，广州 市、深圳市中心城区需有效应对不低于50年一遇的暴雨内涝 ${ }^{[15]}$ 。作为 深圳市未来发展的核心区域，合作区中心城区内涝防治标准被定位为 100 年一遇，与现状 20 年一遇的防涝标准差距甚远，因此需在此方面大
力加强。根据《深圳市排水 (雨水) 防涝综合规划》, 中心城区新建 雨水管渠设计标准重现期为 5 年, 非中心城区为 3 年 ${ }^{[16]}$, 合作区管渠标准 对标深圳市, 与其保持一致, 以协助实现 100 年一遇的防涝标准。按照 《城市水系规划规范（GB 50513-2009，2016年修订版）》相关规定， 确定城市流域水面率应不低于开发前水域比例 ${ }^{[17]}$, 即要求合作区水面率 不低于 $4.97 \%$ 。参照广东省水利厅公布的珠江三角洲河网密度, 合作区 河网密度被控制为不低于珠江三角洲当前河网密度, 即 $0.83 \mathrm{~km} / \mathrm{km}^{2}$, 而 合作区现状 $0.55 \mathrm{~km} / \mathrm{km}^{2}$ 的密度值仍有很大的提升空间 ${ }^{[18]}$

第三, 从土地开发模式来看, 合作区建设必须满足海绵城市建设 核心指标之一的年径流总量的控制要求，通过对降雨的人渗、集蓄、 利用、蒸发等过程进行策略性管理，实现雨水资源调蓄的核心要求。 依照《深圳市海绵城市专项规划（2016）》, 深圳市海绵城市建设年 径流总量控制率不低于 $70 \%$, 条件较好的地区不低于 $75 \%$ 。由于合作 区属于高质量、高标准建设新区, 本方案要求流域内建成区 $90 \%$ 以上的 面积达到 $75 \%$ 的年径流总量控制率。而场地已建成部分均为 $60 \%$ 的现行 标准。

基于上述分析，可以发现合作区范围内各个指标的现状水平与 方案拟定的目标仍存在一定差距, 因此研究方案结合合作区的基地条 


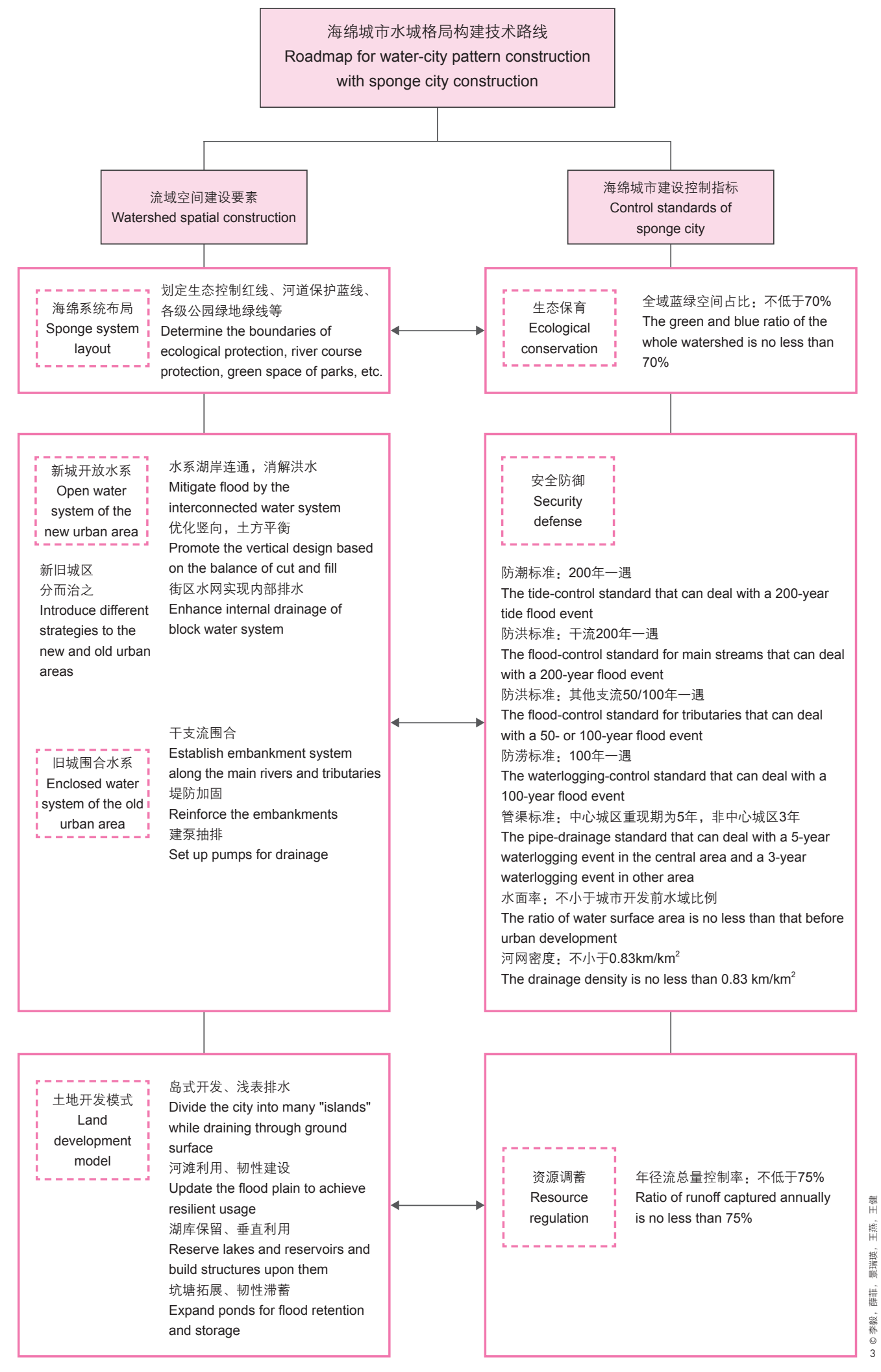

件, 针对上述三个方面提出了更加具体的水城格局构建策略, 以使合 作区从各个方面满足海绵城市建设指标, 为整个流域的防洪安全、生 态涵养等方面提供保障。

\section{3 水城格局构建策略}

\section{1 海绵系统布局}

由于现状蓝绿空间占比与目标值差距较小, 因此研究团队在这一 方面主要强调满足《深汕特别合作区总体规划（2017-2035年）纲要》 的基本要求, 即划定生态空间总面积约 $311 \mathrm{~km}^{2}$, 占比 $66.5 \%$; 划定农业 空间总面积约 $17 \mathrm{~km}^{2}$, 占比 $3.6 \%$; 确保合作区生态系统完整, 蓝绿空间 占比稳定在 $70 \%$ 以上 ${ }^{[20]}$ 。一方面, 需要最大限度地保护现有林地、草 地、河流、湖泊、湿地、坑塘、沟渠等自然要素, 尽量维持城市开发 前的自然水文特征; 另一方面, 也需要科学确定生态保护红线、河道 保护蓝线、公园绿地绿线、永久基本农田和城镇开发边界, 形成依山 面海、林田共生、水城相融、蓝绿交织的全域资源要素空间格局。通 过护山、理水、造林、圩田、成湖等生态与工程手法, 建立通山达海 的生态廊道, 使城镇开发建设对环境敏感区与生物栖息地的影响降至 最低。

\section{2 城市水系构建}

1 ) 保留水面、加密水网: 城市在开发建设初期主要以农业用地、 林地、水域空间等生态用地为主，拥有天然 “流域海绵” ，水文调节 能力良好 (图4)。由于建设用地的急剧扩张, 大量能够㓞性应对雨洪 的支流和坑塘被填埋，随之消失，而保留下来的河道则被改造成下切 的深渠，河流从易于亲近到人水疏远（图5）。因此，亟需引人与自然 和谐共处的低影响开发模式, 以实现土地利用、水环境、水循环的协 调发展（图6)。城市水面率和河网密度直接关系到城市安全与宜居程 度, 而合作区现状水面率较低, 河网密度与目标值仍存在较大差距。 可以通过水源工程、水系工程、景观水体工程、雨水设施工程、街区 浅表排水工程来尽可能地提高这两个指标的数值（图7）。

2 ) 蓄泄兼筹、防避结合: 根据流域上、中、下游的不同水情, 方 案计划在合作区构建蓄泄兼筹、防避结合的防御系统, 以满足城市防 洪、防潮、防涝等目标。在上游山区利用水底山、明溪和北坑三个水 库实现调蓄洪水、削减洪峰; 在人口密集的中游平原区采取防御工程 手段与避险管理手段相结合的思路保障居民生命财产安全; 在下游人 海处保证河道宽度及通畅度, 实现快排快泄。此外, 还需针对基底情 况各异的新旧城区采取不同的应对策略。在旧城区采取以防为主的传 统围合式防御系统, 加固原有堤防, 通过洜站将内部涝水强排人河; 在新城区强调韧性设计、与洪水为友, 采用开放的水网系统, 构建流 域海绵系统以滞蓄洪水, 实现排水和净化雨水, 同时采用雨污分流的 排水体系, 高标准建设雨水管网, 合理布局行泄通道, 使排水管渠满 足相关要求 (图8)。在沿海片区构建珠链式分区风暴潮防御系统，一 
是保留主要人海冲沟, 构建贯通山海的绿色通廊, 形成组团式发展结 构; 二是将海岸带拆分成不同的洪涝区域设防, 使整体防护系统的运 作不受局部片区的影响, 韧性抵御风暴潮; 三是将河湖连通, 实现水 系统的良性循环 (图9)。

\section{3 土地开发模式}

对水资源的调蓄和雨水径流的控制具体到流域空间建设要素, 包 括用地空间立体建设、浅表流雨水排放设计、河滩地综合利用与韧性 建设方式等建设思路。《深汕特别合作区总体规划（2017-2035年）纲 要》确定了 “一心、两轴、三带、四组团” 的城乡空间总体结构 ${ }^{[20]}$ 。本 案例聚焦 “一心”一围绕政务文化片区和高铁站片区形成的具有综 合功能的区域中心组团，通过4项具体的空间设计手段，实现以资源调 蓄带动均衡发展的土地开发模式 ( 图10)。

1 ) 岛式开发: 首先, 根据片区水文要素, 明确划定适宜开发建设 的用地范围。其次, 在保留赤石河支流水脉的基础上, 利用主要路网 的防护绿带新开水道, 与现有坑塘水系相连通, 并采用街区雨水浅表 排水方式, 超过排水能力的雨水则会溢流到市政管网中。同时, 构建 独具特色的岛屿式开发用地组团, 创造更多的滨水界面, 沿线布置文 化艺术、公共服务、商业配套等用地, 激发地区活力。

2) 河滩利用: 保留赤石河和明热河主干滩涂地, 按照防洪规划要 求构建行洪滩区, 并构建可被淹没的亲水空间, 供非行洪时段使用。 新建城区通过优化地块坚向设计和堤路结合来满足防洪需求; 老城区 则通过河岸微地形塑造，打造隐形防洪堤。

3 ) 湖库保留: 河流沿线分布着大量与其相连的湖库, 它们在拦截 洪水、减轻洪水影响方面发挥着重要作用, 应予以保留。同时, 考虑 到城市发展的需要, 可在湖库保留区域内设置教育、文化等低排污公 共设施，形成立体布局，保证空间复合利用与土地集约化发展。

4) 坑塘拓展: 在零散分布的公园绿地中拓展坑塘湿地等雨水基础 设施, 使其不仅能作为休闲游惒场地, 还兼具雨水收集、调蓄、净化 等功能, 同时提升片区的水面率。新开的水道将其串联起来, 形成完 整的区域海绵系统。

\section{4 讨论与反思}

本研究聚焦于深汕特别合作区的水城格局研究, 将流域空间建 设要素与海绵城市建设相关控制指标进行关联对应, 详细讨论了海绵 系统布局、城市水系规划、土地开发模式三个方面的策略。首先, 科 学确定生态保护红线、河道保护蓝线、公园绿地绿线、永久基本农田 和城镇开发边界, 减少城市开发建设活动对生态系统功能的扰动; 其 次, 充分利用流域现有的山、塘、库、湖的调节功能, 打造渗、滞、 蓄、净、用、排有机结合的水系统, 提高雨洪资源的利用效率, 同时 结合区域发展, 实现被填埋的河道、湿地、坑塘等水系的修复与连 通, 最大限度实现气候水文调节与风暴潮防护, 有效应对极端气候下
的城市水问题; 最后, 优化城市内部空间结构, 实现以资源调蓄带动 土地开发的均衡发展。虽然这三个方面的策略分别与生态保育、安全 防御、资源调蓄三大类指标存在对应关系, 但在实际规划建设的过程 中, 一种策略往往会促进多个指标值的提升, 协同发挥作用。在合作 区即将进入高速发展之际, 本文通过研究合作区水城关系构建策略, 探讨了通过流域尺度海绵城市建设提升促进绿色可持续发展的创新思 路。对标世界三大湾区, 合作区在水系空间规划管控和骨干性工程建 设上还存在一定差距。我们将继续探索, 以期为类似项目抛砖引玉, 提供思路。LAF

\section{项目信息}

项目地址：中国深汕特别合作区

项目面积: $468 \mathrm{~km}^{2}$

项目委托: 深圳市水务局

项目负责人: 王燕

研究团队: 李毅、王健、薛菲、成洁、景瑞塔、宋航、陈珊、孙翔、张宏图、黄奕龙、杜朋辉、刘雪朋、 卢巧慧、朱嘉琳、李园园

研究时间：2018年9 12月
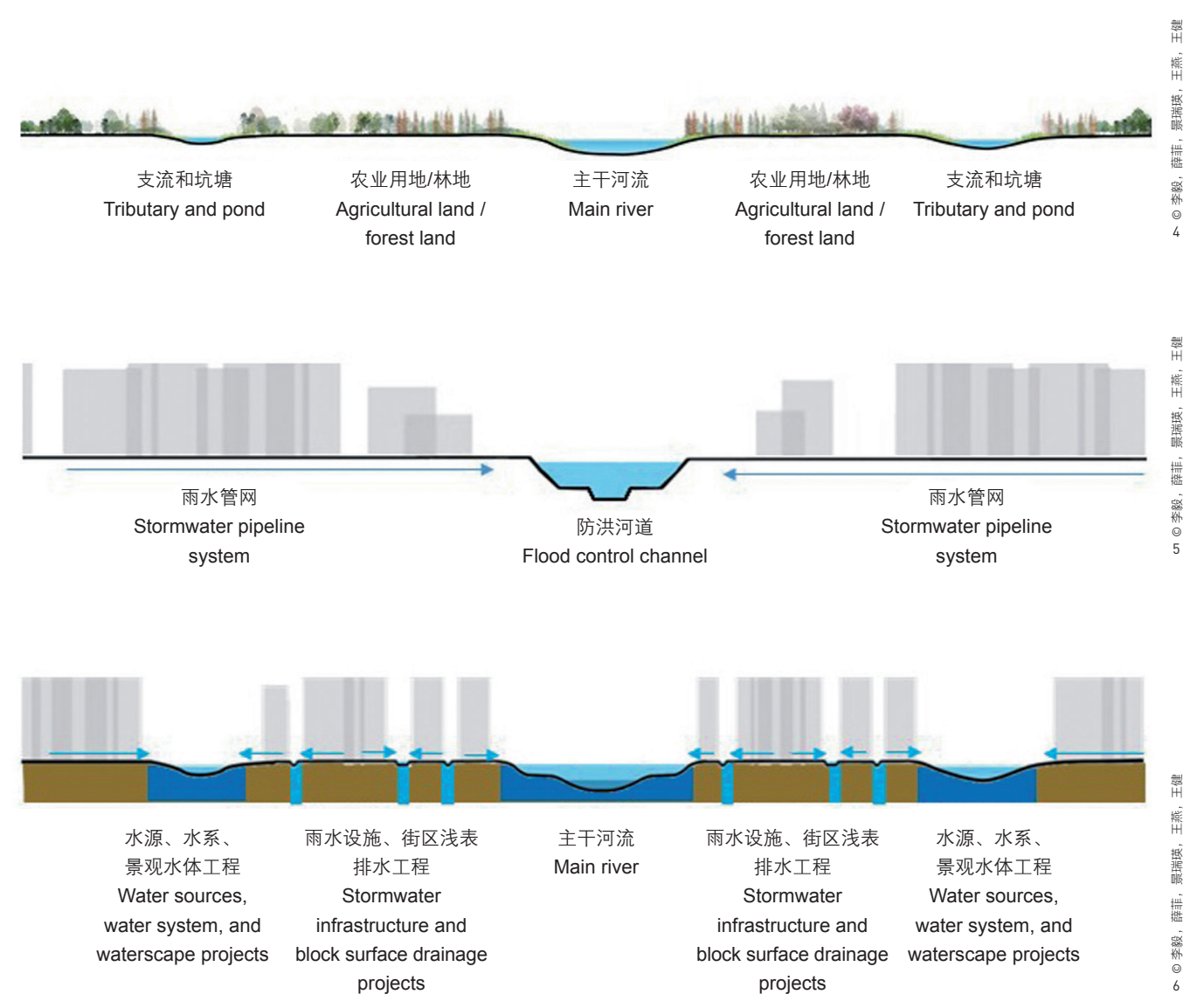


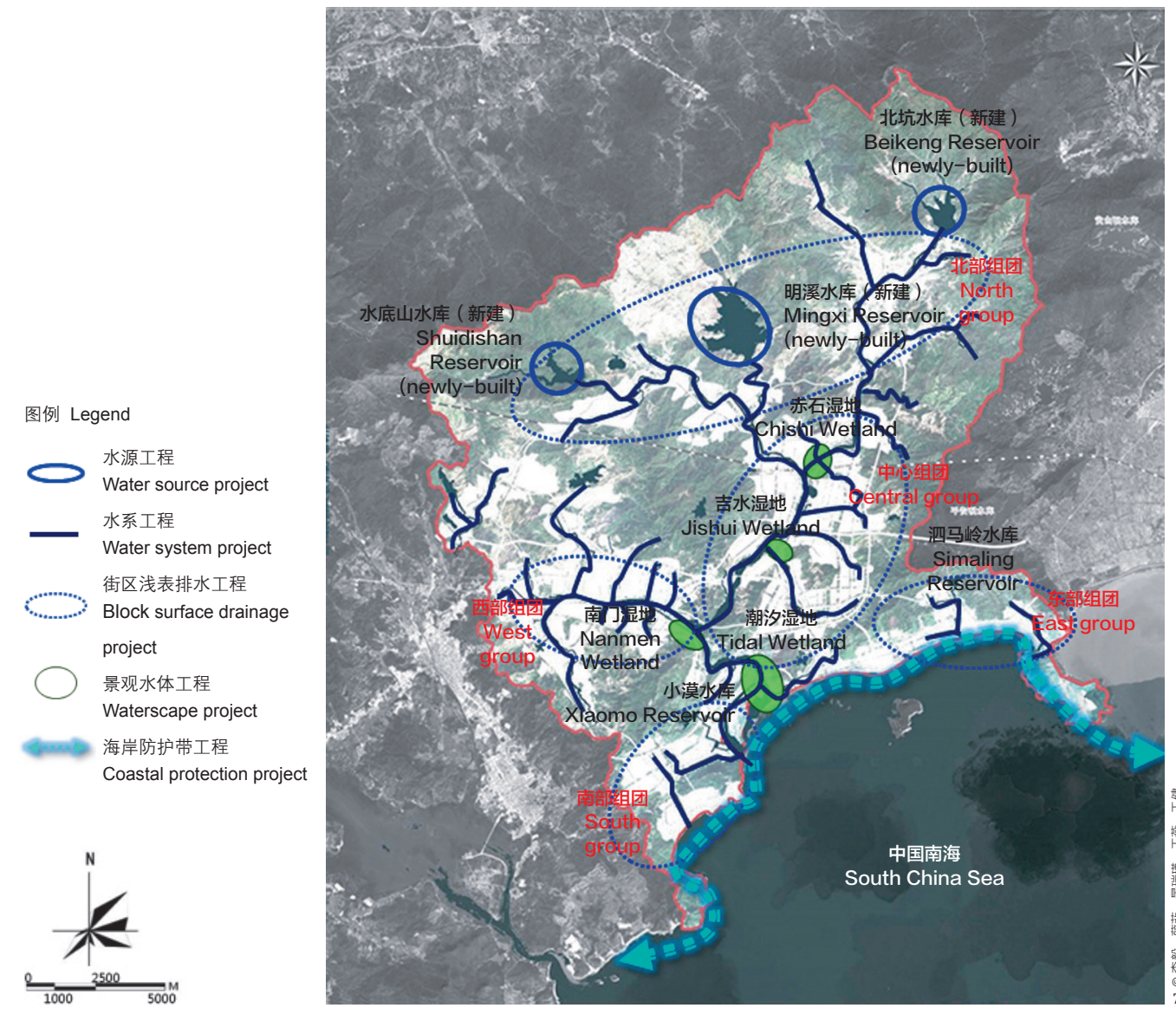

4. 城市在开发建设初期的 土地利用方式 土地利用方式 5. 传统的城市排水模式 水系先导下的城市排水
模式

利用工程措施提升水面 率和河网密度

4. Land use in the initial stage of urban development

5. Traditional urban drainage mode

. Urban drainage mode oriented by the waterway instead of the pipeline system

7. Improve water surface ratio and drainage density through engineering measures

\section{Project Background}

Located to the east of the Pearl River Delta plain in Guangdong Province, China, the ShenShan Special Cooperation Zone (SSSCZ) is a key node linking the eastern Guangdong area with the Guangdong-Hong Kong-Macau Greater Bay Area and the Pearl River Delta. The SSSCZ is composed of Ebu, Xiaomo, Houmen, and Chishi Towns with a total area of $468 \mathrm{~km}^{2}$. In February 2011, SSSCZ was founded under the background of advancing reform and openingup in the new era and coordinating regional development in Guangdong. Since 2017, besides 10 existing districts, the SSSCZ has become a new district of Shenzhen (Fig. 1).

The SSSCZ is mountainous in the north with terraces and hills in the midland and coastal plains in the south. Intertwining forests and farmlands, dense water networks as well as numerous lakes and reservoirs endow this area a sound sponge basis. There are forests of $353 \mathrm{~km}^{2}$ along the Lianhua Mountains in the north, farmlands of $36 \mathrm{~km}^{2}, 6$ small-scale ( I ) reservoirs, 22 small-scale ( II ) reservoirs, 54-kilometer coastal lines, 13-kilometer continuous beach with high quality, rivers with a water quality of grade II and III, and lots of ponds and wetlands. The Chishi River, a predominant river of the SSSCZ, runs across the area from north to south with two first-class tributaries, namely the Mingre River and the Nanmen River, and other subdivided flows. The watershed of Chishi River covers 382 square kilometers, accounting for $81.6 \%$ of the total area of the SSSCZ, while the remaining $18.4 \%$ area is occupied by the catchment of coastal rivers reaching the sea directly.

In spite of the sound sponge basis, the SSSCZ is still faced with several challenges.

1) Severe ecological conditions: The lands suitable for development are limited because of the hilly topography and concentrate in the river valley terraces in the midland and the coastal plains in the south, accounting for $30 \%$ of the total area.

The development of the industrial cluster in the west brings serious conflicts between human's demands and the protected water area. The water courses of tributary were diverted, cut off, or occupied for other uses, with a dramatic decrease of wetlands, significantly damaging the ecological hydrologic process. The accelerated urban development and increasing land demand make it inevitable to avoid impact on the natural resources, challenging the ecological security of the watershed.

2) Increasing flood risks: The coastline of the SSSCZ is vulnerable to typhoons with frequent floods and waterlogging due to the dense water network and rapid conflux from the steep gradient. However, existing flood control infrastructure, including the river channels and sea embankments, can hardly meet the flood prevention standards during the flood season. With the expansion of built areas, the increasing impervious surface ratio, runoff coefficient, and peak discharge aggravate the flood risks and threaten residents' life and property.

3) Shortage of freshwater resource: The area between the intersection of the Mingre River and the Chishi River and the marine outfall is influenced by salt tides, reducing the freshwater resource supply. Worse, located in the underground water source conservation area of Guangdong, the SSSCZ suffers from frequent geological disasters, which makes it impossible to develop the underground water resource, aggravating the supply-demard contradiction and challenging the sustainable utilization of freshwater resource.

\section{Project Roadmap}

The core value of the sponge city construction is to keep urban ecosystem safe and healthy ${ }^{[1][2]}$, and it covers several aspects 


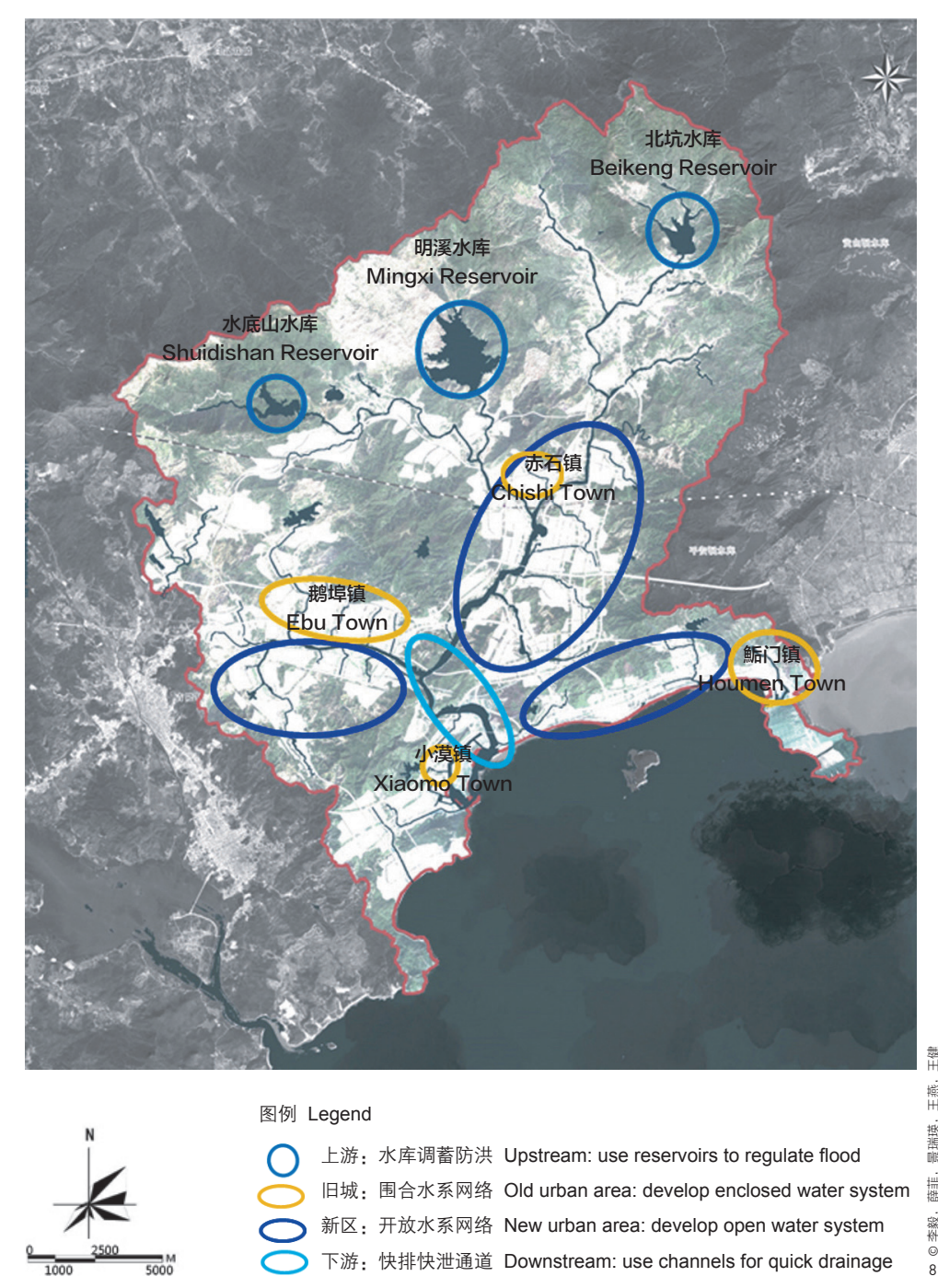

including water safety, water environment, water ecology, water resources, and institution establishment ${ }^{[3] \sim[5]}$. A large number of studies have focused on core element such as the total runoff volume capture, the peak runoff control, and the runoff pollution control $^{[6] \sim 10]}$. This article explores the spatial pattern of water in SSSCZ and studies sponge elements related to the sponge system layout, the waterway planning in the old and new urban areas, and the land development mode. It also proposes sponge city construction strategies at the watershed scale based on natural resources of mountains, rivers, forests, farmlands, and lakes ${ }^{[11]}$.

With the guidance of national and local regulations, the research team establishes the correspondence between the watershed spatial construction and the control standard of sponge city, providing rigid norms for future urban development in the zone to ensure the safety and health of the whole watershed (Fig. 3).

First, in terms of the sponge system layout, emphasis should be put on the blue and green space ratio controlled by ecological conservation. The Management Regulations on the Basic Ecological Control Line in Shenzhen (2005) includes nearly $50 \%$ of the natural areas into the conservation area despite of the extreme scarcity of the land resources ${ }^{[12]}$. The plan slightly raises the blue and green space ratio from current $69.1 \%$ to targeted $70 \%$ with Xiong'an New District as a benchmark ${ }^{[13]}$ to guarantee the safety and health of urban ecosystem services.

Second, from the aspect of urban waterway planning, the plan sets multi-dimensional and high-standard prevention standards and adopts different measures in the old and new urban areas. With a proposed population of over 1.5 million, the protection level of SSSCZ is Grade I (significantly important), and it is supposed to deal with a 200 -year (100-year for now) flood tide; main streams should deal with a 200-year (50-year for now) flood event while other tributaries should resist 50- or 100-year (20year for now) flood event. It can be seen that there is a wide gap between the existing situations and the proposed ones. According to the Standards for Waterlogging Control (SL723-2016), the design standard of the urban area vulnerable to waterlogging should be set based on the economic conditions and permanent resident population ${ }^{[14]}$. As required by the Guideline on Construction of Urban Drainage and Waterlogging-Control Infrastructure issued by the Government of Guangdong Province in 2014, the downtown areas of Guangzhou and Shenzhen should be able to handle the waterlogging caused by a 50 -year flood event ${ }^{[15]}$. As the core area of Shenzhen in the near future, SSSCZ is expected to deal with the waterlogging caused by a 100 -year flood event which is much higher than its current capability to withstand a 20-year flood event. The Comprehensive Planning of Stormwater Drainage and Waterlogging Control in Shenzhen requires the pipeline system to deal with a 5-year waterlogging event in the city center and a 3-year waterlogging event in other areas ${ }^{[16]}$, which provides a benchmark for the pipe-drainage standard for SSSCZ so that the goal of waterlogging control could be achieved. In accordance with the Code for Waterway Planning (GB 50513-2009, revised in 2016), the water surface ratio of a new district should be no less than that before the development ${ }^{[17]}$. This standard for SSSCZ is $4.97 \%$. In addition, the river network density of SSSCZ should be raised from $0.55 \mathrm{~km} / \mathrm{km}^{2}$ to $0.83 \mathrm{~km} / \mathrm{km}^{2}$, with a reference to the density of the Pearl River Delta released by the Water Resources Department of Guangdong Province ${ }^{[18]}$.

Third, SSSCZ should meet the requirement for the annual runoff control, a key element of sponge city construction, in terms of the land development mode. By managing the process of stormwater infiltration, storage, utilization, and vaporization strategically, the regulation of water resources can be achieved. As
8. 蓄泄萧筹、防避结合的 洪水防御系统 珠链式分区防御系统

8. Prevent and control the flood by means of storage and discharge 9. A zoning storm surge defence chain 
stated in the Sponge City Subject Planning of Shenzhen in 2016, more than $70 \%$ of the annual runoff should be captured with the goal rate of $75 \%$ setting for areas with better conditions ${ }^{[19]}$. As a new area with high construction standard, over $90 \%$ of the SSSCZ area should meet the standard of a control rate of $75 \%$ while the existing area remains the current standard of $60 \%$.

The analysis above suggests that there is a gap between the existing conditions and the new standards. The plan therefore proposes more detailed strategies in the consideration of the site conditions to ensure that water-city pattern development in SSSCZ meets the criteria of sponge city construction, providing a guarantee for flood control and ecological conservation in the whole watershed.

\section{Water-City Pattern Construction Strategies}

\subsection{Sponge System Layout}

Since the current proportion of the blue and green space is close to the target, the research team just puts emphasis on the basic requirements of the Outline of the ShenShan Special Cooperation Zone Master Plan (2017-2035), that is, to define the ecological space $\left(311 \mathrm{~km}^{2}\right)$ and agricultural space

$\left(17 \mathrm{~km}^{2}\right)$, accounting for $66.5 \%$ and $3.6 \%$ respectively, and ensure the integrity of the ecosystem with more than $70 \%$ of the blue and green space in this are ${ }^{[20]}$. On one hand, it is important to maximize the protection of existing natural elements including forests, grasslands, rivers, lakes, wetlands, ponds, ditches, etc. to maintain the hydrological characteristics; on the other hand, boundaries of ecological protection, river course protection,

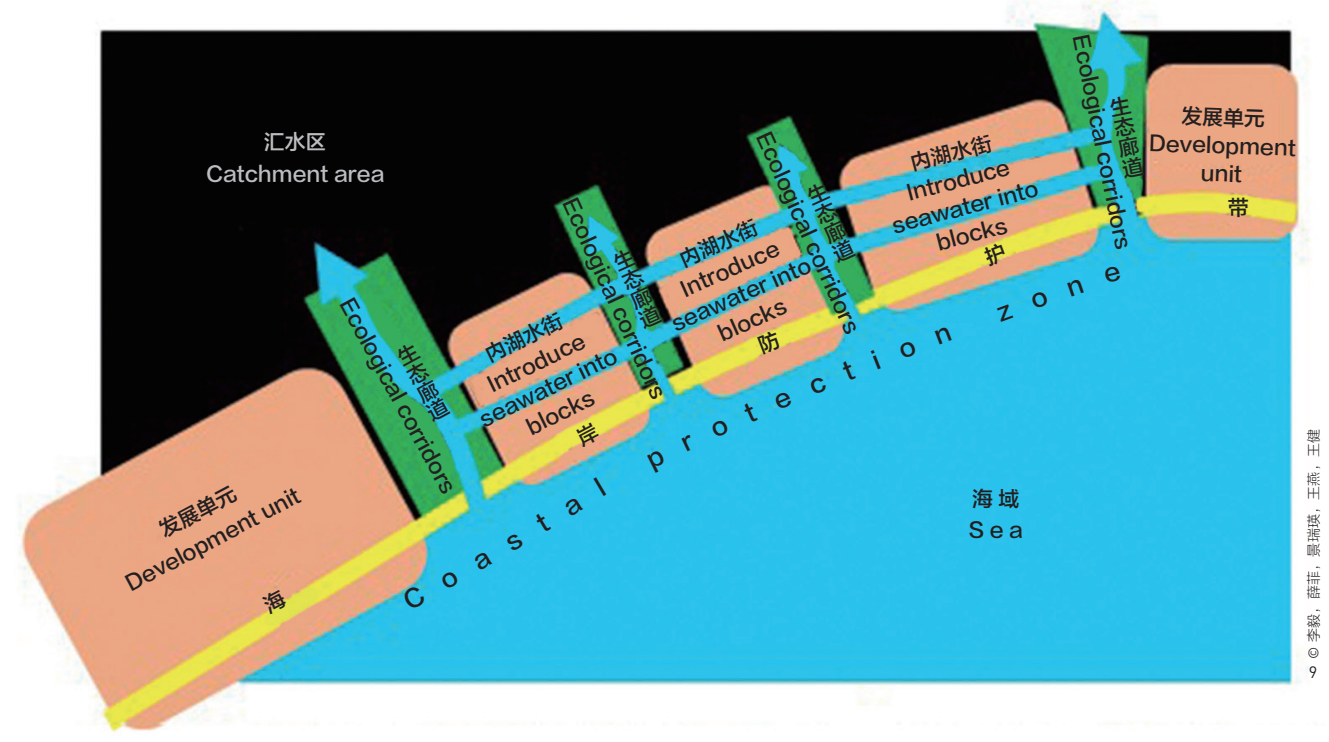

green space of parks, permanent basic farmland, and urban development are supposed to be determined scientifically to form a regional resource spatial pattern with a harmonious coexistence of forests, farmlands, rivers, and cities. Ecological corridors should be established by ecological and engineering techniques such as forest protection, waterscape design, afforestation, construction of polders and lakes, etc. to connect different patches to protect the environmental sensitive areas and habitats from the impacts of urban development.

\subsection{Urban Water System Construction}

1) Retain the water surface and densify the water network: In the initial stage of urban development, ecological lands such as farmlands, woodlands, and waterbody almost occupied this area, forming a natural "watershed sponge" there with high hydrological adjustment ability (Fig. 4). Due to the rapid urbanization, a large number of tributaries and ponds capable of responding to stormwater were buried then disappeared, while the remaining river courses were transformed into deep pitches, making rivers isolated from people (Fig. 5). Therefore, a low impact development mode to achieve coordinated development of land use, water environment, and water cycle is needed (Fig. 6). Closely related to urban safety and livability, the water surface ratio and drainage density of the city, however, are quite low in the SSSCZ, where there is a large gap between the current values and the target ones. These values can be increased by the developments of water source, water system, waterscape, stormwater infrastructure, and block surface drainage projects (Fig. 7).

2) Prevent and control the flood by means of storage and discharge: According to different conditions in the upper, middle, and lower reaches of the watershed, a defense system would be built in the SSSCZ to control flood, flood tide, and waterlogging. In the upper mountainous area, three reservoirs of Shuidishan, Mingxi, and Beikeng are used for flood regulation and peak reduction; in the populous middle reaches plain, a combination means of defense works and risk management is adopted to safeguard the lives and property of residents; near the mouth of the sea in the downstream, sufficient width and smoothness of the river courses are the guarantee of fast discharge. In addition, corresponding strategies should be adopted in new and old urban areas in consideration of different base conditions. In the old urban area, a traditional enclosed defence system is planned to strengthen the existing embankments, and the internal waterlogging would be pumped out; an open water system would be established in the new urban area to construct a resilient watershed sponge system for flood storage, retention, discharge, and purification with a rainwater and sewage diversion system built in a high standard 


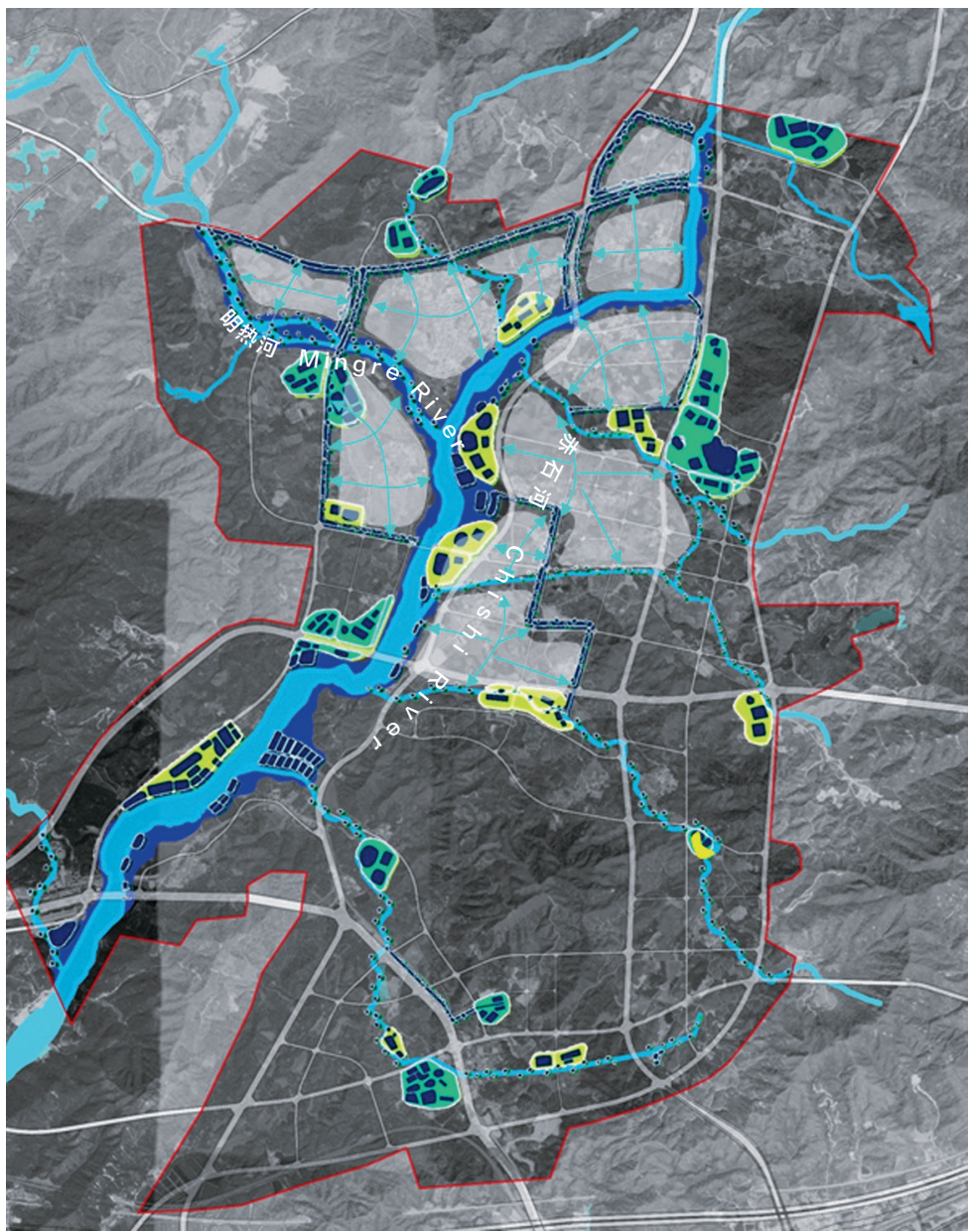

and elaborate layout (Fig. 8). In the coastal area, a zoning storm surge defense chain would be established. The green corridors built based on main gullies links the north mountainous areas and the sea and divides the coastal area into many development clusters. Each cluster is equipped with independent flood-control infrastructures, strengthening the resilience of the whole defense system against storm surge attacks. It also connects the rivers and lakes to create a robust cycle of the water system (Fig. 9).

\subsection{Land Development Model}

Watershed spatial construction strategies such as vertical design, surface drainage design, comprehensive development of the flood plains, and resilient enhancement would contribute to the water resource regulation and runoff control. The Outline of the ShenShan Special Cooperation Zone Master Plan (2017-2035) defines the overall structure of the urban and rural space with "one center, two axes, three belts and four clusters" ${ }^{[20]}$. Taking the political, cultural, and transportation central area of SSSCZ,
10. 针对中心组团的空间设 计手段

10. Spatial design methods of the central group

图例 Legend

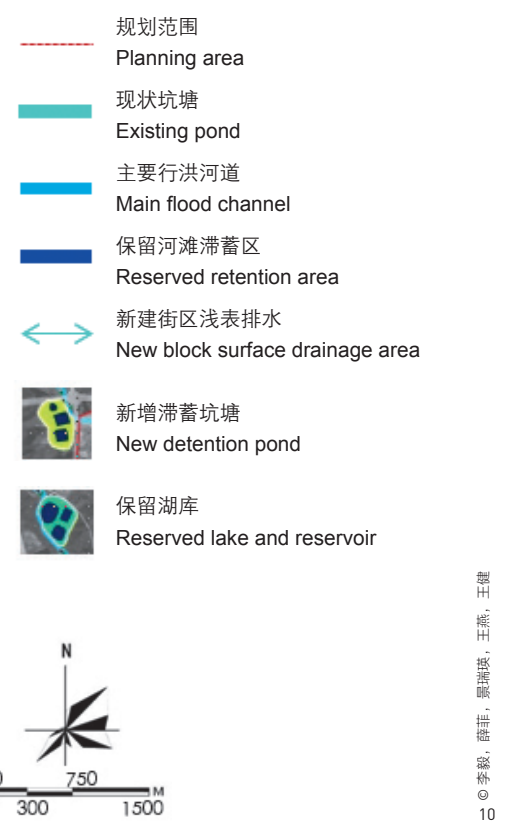

namely the "center," as an example, this project suggests four spatial design methods to realize a balanced land development mode with resource regulation (Fig. 10).

1) Divide the zone into many "islands": First, define the potential development land according to the hydrological condition of the district. Then, transform the green buffers along the main streets into water courses to integrate existing ponds and the retained tributaries of the Chishi River as a whole. Most runoff is controlled by surface drainage while the surplus overflow is led to municipal pipes. Meanwhile, the unique island-like development groups creates more waterfront interfaces, along which lands for culture and arts, public service, and commercial facilities could be planned to stimulate regional vitality.

2) Take full advantage of the flood plains: Reserve the main mudflats of the Chishi River and the Mingre River, construct the floodplain zones according to the requirements of flood control planning, and design a hydrophilic space for recreation which also could be inundated in rainy season. In order to meet the requirement 
of flood control, the new urban area optimize the vertical design and develop dike and road system collaboratively; in the old urban area, the dikes are embedded into the micro-topography engineering to shape the riparian landscape.

3) Reserve existing lakes and reservoirs: Reserve numerous lakes and reservoirs along the rivers which play an important role in flood control and impact mitigation. At the same time, considering the needs of urban development, public facilities with low sewage discharge for educational and cultural functions can be set up vertically upon the reserved areas to achieve multilayer land use and intensive development.

4) Introduce more ponds: Introduce ponds and other stormwater infrastructures into scattered parks / green spaces, not only to serve as recreation sites, but also to collect, regulate, storage, and purify the rainwater, as well as improve water surface ratio of the district. They could be connected by the newly-built waterways, forming a comprehensive regional sponge system.

\section{Discussion and Reflection}

Attempting to correlate the watershed spatial construction and the control standards of sponge city, this study explores the water-city pattern development strategies in the SSSCZ from three aspects: 1) sponge system layout, to scientifically determine the boundaries of ecological protection, river course protection, green space of parks, permanent basic farmland, and urban development to minimize the intervention of urban development to ecosystem services; 2) urban waterway planning, to take full advantage of the regulation capability of existing mountains, ponds, reservoirs, and lakes in the watershed to enhance the reuse of stormwater through a complete water process system including infiltration, retention, storage, purification, utilization, and drainage. Meanwhile, take the restoration and connection of the buried rivers, wetlands, and ponds as part of the regional development to maximize the capacity of hydrological regulation and storm tides control and effectively cope with water problems in extreme climate; and 3) land development mode, to achieve a balanced land development driven by resource regulation with urban spatial structure optimization. Although these strategies are corresponding to the standards of ecological conservation, security defense, and resource regulation respectively, one strategy generally promotes values of multiple standards working synergistically in the practice of planning and construction. As the SSSCZ is going to start a high-speed development, this article studies strategies of the water-city pattern construction and discusses the innovation methods of promoting sustainable development with sponge city construction at the watershed scale. However, compared with three Greater Bay Areas worldwide, the SSSCZ is insufficient in spatial planning and management of water system and flagship program construction. More exploration should and would be done to provide reference for similar projects. LAF

\section{PROJECT INFORMATION}

Location: ShenShan Special Cooperation Zone, China

Area (size): $468 \mathrm{~km}^{2}$

Client: Water Resources Bureau of Shenzhen Municipality

Project Leader: Wang Yan

Project Team: Li Yi, Wang Jian, Xue Fei, Cheng Jie, Jing Ruiying, Song Hang, Chen Shan, Sun Xiang, Zhang Hongtu, Huang Yilong, Du Penghui, Liu Xuepeng, Lu Qiaohui, Zhu Jialin, Li Yuanyuan Research Period: September December, 2018

\section{REFERENCES}

[1] Yu, K., Li, D., Yuan, H., Fu, W., Qiao, Q., \& Wang, S. (2015). "Sponge City": Theory and Practice. City Planning Review, 39(6), 26-36. doi:10.11819/cpr20150605a

[2] Yu, K. (2015). Key technologies for construction of water ecological infrastructures. China Water Resources, (22), 1-4. doi:10.3969/j.issn. 1000-1123.2015.22.002

[3] Ma, H., Zhou, D., Kang, C., \& Wang, J. (2016). Sponge City Planning Theory and Zhuhai's Practice. Planners, 32(5), 29-34. doi:10.3969/j.issn. 1006-0022.2016.05.005

[4] Urban Planning, Land and Resources Commission of Shenzhen Municipality. (2016). Special planning and implementation plan of the sponge city construction of Shenzhen (text). Retrieved from http:// www.sz.gov.cn/cn/xxgk/zfxxgj/ghjh/csgh/zxgh/201711/t20171121_9903627.htm

[5] Wang, Y. (2016). Regulatory Planning Indices for Sponge City Development. Planners, 32(5), 10-16. doi:10.3969/j.issn. 1006-0022.2016.05.002

[6] Ren, X., \& Tang, J. (2015). Application of Capture Ratio of Total Annual Runoff Volume in Spongy City. China Water \& Wastewater, 31(13), 105-109.

[7] Shi, Y. (2017). Study and Analysis on Runoff Pollution Control in Sponge City Planning - Take Zhuzhou as an Example. China Municipal Engineering, 191(2), 72-74. doi:10.3969/j.issn. 1004-4655.2017.02.022

8] Wang, W., Li, J., Che, W., \& Zhao, Y. (2015). Explanation of Sponge City Development Technical Guide: Planning Indicator for Urban Total Runoff Volume Capture. China Water \& Wastewater, 31 (8), 18-23.

[9] Zhang, K., \& Che, W. (2016). Study on Urban Runoff Pollution under the Background of Sponge City Construction. Construction Science and Technology, (1), 32-36. doi:10.16116/j.cnki.jskj.2016.01.006

[10] Ministry of Housing and Urban-Rural Development of the People's Republic of China. (2014). Technical Guide for Sponge City Construction - Construction of Rainwater System with Low Impact Development (Trial). Beijing.

[11] Zhu, W., Wang, J., Xue, F., \& Chen, S. (2018). Integrated Solutions for Urban Water Issues. Nanjing Phoenix Science Press.

[12] Sheng, M. (2010). From the Planning Formulation to Policy Design: Empirical Study and Reflection on Shenzhen Basic Ecological Control Line. Urban Planning Forum, s1(7), 48-53. doi:10.3969/ j.issn. 1000-3363.2010.z1.009

[13] Kuang, W., Yang, T., \& Yan, F. (2017). Regional urban land-cover characteristics and ecological regulation during the construction of Xiong'an New District, Hebei Province, China. Acta Geographica Sinica, 72(6), 947-959. doi:10.11821/dlxb201706001

[14] Ministry of Water Resources of the People's Republic of China. (2016). Standards for waterlogging control (No. SL 723-2016). Beijing: China Water and Power Press.

[15] People's Government of Guangdong Province. (2014). Guideline on Construction of Urban Drainage and Waterlogging-Control Infrastructure. Retrieved from http://zwgk.gd.gov.cn/006939748/201404/ t20140404_488457.html

[16] Urban Planning, Land and Resources Commission of Shenzhen Municipality, \& Water Resources Bureau of Shenzhen Municipality. (2015). Comprehensive Planning of Stormwater Drainage and Waterlogging Control in Shenzhen. Retrieved from http://www.suprc.org/product-fruit-i_8854.htm

[17] Ministry of Housing and Urban-Rural Development of the People's Republic of China. (2016). Code for Waterway Planning (GB 50513-2009, revised in 2016). Beijing: China Planning Press.

[18] Water Resources Department of Guangdong Province. (2018). The Rivers of the Pearl River Delta. Retrieved from http://www.gdwater.gov.cn/yszx/ysgk/sxyszy/h/201804/t20180410_303493.shtml

[19] Bureau of Planning and Natural Resources of Shenzhen. (2017). Sponge City Subject Planning of Shenzhen. Retrieved from http://www.sz.gov.cn/cn/xxgk/zfxxgj/ghjh/csgh/zxgh/201711/ t20171121_9903627.htm

[20] Bureau of Planning and Natural Resources of Shenzhen. (2017). Outline of the Master Planning for ShenShan Special Cooperation Zone (2017-2035). Shenzhen: Bureau of Planning and Natural Resources of Shenzhen. 